\title{
Julio Alejandro Barrera Bugallo
}

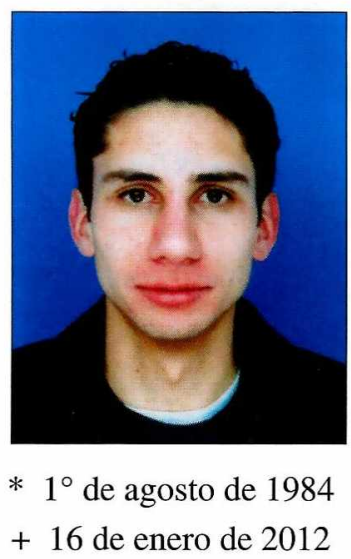

Estudiante de medicina de la Fundación Universitaria de Ciencias de la Salud, amigo y compañero de tantos que caminaron junto a él por las instalaciones de nuestra casa formativa, para culminar con éxito la labor más noble que puede existir, la medicina.

Siempre nos demostró con su forma de ser, de hablar y de sentir, que la seguridad con que caminamos a diario hace de cada uno de nosotros un ser único; seguridad con la que él, hace unos años, decidió sin descanso dedicarse de todo corazón a esta profesión.

Este amigo al que consideramos grandioso no solo por su conocimiento y su intelecto sino por la serenidad que lo caracterizó, hoy nos deja el recuerdo de que la labor se hizo con entrega, dedicación y esmero. Siempre estudioso, competitivo y amante del conocimiento, fue por cinco años el ejemplo a seguir.

A quienes fuimos sus compañeros y amigos nos deja un legado: con paciencia y constancia podremos alcanzar el conocimiento, y que la razón y el saber cuando van juntos logran beneficios que para muchos hombres son inalcanzables.

Siempre lo recordaremos con una sonrisa. La alegría de haber compartido con él perdurará en la memoria, en el recuerdo y en el corazón de sus amigos, aunque el dolor invade el alma de quienes lo vimos partir a sus 27 años de edad.

A su padre Julio Barrera, a su madre Martha Bugallo y a sus hermanos David y Andrés, un abrazo de condolencia y un deseo profundo de discernimiento y sabiduría.

Andrés Fernando García Velasco

Representante Internos XI Semestre 